\title{
LUT
}

Lappeenranta

University of Technology

Reasons for choosing mechanisms to protect knowledge and innovations

Olander Heidi, Vanhala Mika, Hurmelinna-Laukkanen Pia

This is a Final draft

version of a publication

published by Emerald

in Management Decision

DOI: $10.1108 / M D-11-2012-0791$

Copyright of the original publication: (C) 2019 Emerald Publishing Limited

Please cite the publication as follows:

Olander, H., Vanhala, M. and Hurmelinna-Laukkanen, P. (2014). Reasons for choosing mechanisms to protect knowledge and innovations. Management Decision, Vol. 52 No. 2. p. 207-229. DOI: 10.1108/MD-11-2012-0791

This is a parallel published version of an original publication. This version can differ from the original published article. 


\section{Reasons for choosing mechanisms to protect knowledge and innovations}

\section{Introduction}

Following the focus on core competences in the firm's R\&D strategy in recent decades, the tendency nowadays is towards collaboration. Given the increase in complexity of technological development, the pace of innovation cycles and the higher risks and costs, firms need to use external partners in their R\&D (Bader, 2008). They also need complementary knowledge from different collaboration partners. Thus, an increasing proportion of innovations take place outside the boundaries of the firm, which highlights the importance of intellectual property (Bader, 2008).

Companies engaged in $R \& D$ collaboration aim at the creation of new knowledge, innovation, or the solving of a problem. In order to achieve the desired outcomes they need to share as much of the right kind knowledge as possible with their collaboration partners. However, they tend to have concerns related to issues such as the ownership of intellectual property and the transfer of intellectual capital (especially in terms of knowledge they wish to preserve that is critical to their future success) (Heiman and Nickerson, 2004).

Generating innovations with commercial value is also likely to attract the attention of competitors, who will try to enter the same markets or imitate the innovation (HurmelinnaLaukkanen, 2009). The firm is not totally vulnerable to the actions of others, however. Indeed, there are many protective mechanisms through which it can prevent or limit the imitation of its core knowledge assets and innovations, thereby both enabling value-creation endeavours and improving value-capturing opportunities. These mechanisms are called appropriability mechanisms.

Although the common denominator is increased exclusivity, there is a wide range of appropriability mechanisms. The mechanisms for governing risks related to the protection of intellectual property and of knowledge include intellectual property rights (IPRs), which have been quite extensively studied (Cohen et al., 2000; Davis, 2004; Hertzfeld et al., 2006; Lang, 2001). IPRs 
comprise patents, copyrights, trademarks, trade names, utility models and trade secrets, to mention the most common ones. There are also various types of contracts geared to protecting knowledge (Hertzfeld et al., 2006 Klein Woolthuis et al., 2005; Reuer and Ariño, 2005). Mechanisms related to labour legislation and human resource management (HRM) (Baughn et al., 1997; HurmelinnaLaukkanen and Puumalainen, 2007) have attracted less research attention, despite their potential in terms of protecting the intellectual assets embodied within the firm's personnel. Secrecy (Arundel, 2001) and lead time (Leiponen and Byma, 2009; Lieberman and Montgomery, 1988) are mentioned in some studies as being among the most efficient knowledge-protection mechanisms, and finally, tacitness and complexity are also effective in protecting core knowledge (Norman, 2002). These mechanisms are categorised in different ways. There are various definitions of trade secrets, for example, which accordingly may be included in IPRs or seen as individual means of protection. However, in general, protection mechanisms can be classified as informal (non-statutory) or formal (statutory) (see, e.g., Gallié and Legros 2012, Neuhäusler 2012). The main difference between them is that the latter are mechanisms of enforcement established on the institutional level. In this study formal protection comprises IPRs and contracts, whereas informal protection comprises HRM, tacitness and secrecy.

Firms frequently use a combination of formal and informal mechanisms, but with a few exceptions (e.g., Cohen et al., 2000, Hurmelinna-Laukkanen and Puumalainen, 2007) there is a lack of research on the reasons behind their choice (Hall et al., 2012). Our intention in this study is to shed light on this issue by identifying some of the motives and needs behind the protection of intellectual assets, and then empirically examining how they relate to the choice of mechanisms.

Prior research has shown that knowledge-protection mechanisms are used in R\&D collaboration between partners (e.g., Norman, 2002). Firms with IPR protection may feel more inclined to collaborate because of the smaller perceived risk. Registered rights should also guarantee freedom of operation in the future and prevent imitation on the part of partners or rivals. Existing IPRs may help collaborating firms to determine who owns what, and may subsequently ease the transfer of 
different intangibles. Nevertheless, on account of the expense and complexity involved in acquiring effective protection for intellectual property, some firms fail to cover their innovations with IPRs. This seems to be a problem especially among SMEs, which may lack resources (e.g., Olander et al., 2009). There is therefore a need to find alternative ways of protecting knowledge and innovations, in which regard informal mechanisms may be of value. However, the choice is far from straightforward.

Although there are numerous discussions covering the use of formal mechanisms in collaboration, especially IPRs, there is a lack of quantitative research on the relationship between the reasons underlying reliance on protection and the choice of formal governance as a strategy. Moreover, there is little research on the combined use of formal and informal mechanisms (for exceptions see Galende, 2006; Hurmelinna-Laukkanen and Puumalainen 2007; HurmelinnaLaukkanen, 2009). The novelty of this study lies in the investigation of thus far under-researched informal mechanisms (see e.g., Galende, 2006), and in its focus on those related to HRM, which are less familiar and less extensively studied. It is hypothesised that firms with several options in terms of acquiring protection, and different related aims and needs, choose different mechanisms through which to achieve it. The research question addressed in the study is therefore the following: What are the reasons behind firms' choices regarding the use of formal or informal mechanisms in protecting their knowledge and innovations?

We proceed as follows. A review of the relevant literature on knowledge and innovation protection and knowledge management sets the framework. The next step is to construct a model illustrating the hypothetical relationships, which provides a basis for the hypothesis testing: quantitative survey data from 209 R\&D-intensive firms is subjected to linear regression analysis. The results of the analyses are described and evaluated in the discussion section, and the concluding section points out the theoretical and managerial implications. 


\section{Theory and hypotheses}

\subsection{Value creation and value capture in $R \& D$ collaboration - the role of protection}

Value creation and value capture form a continuum within which uniqueness of knowledge plays a central role. It has been noted that a firm that is able to create more value than its rivals has a competitive advantage (Porter, 1985; Adner and Kapoor, 2010). Furthermore, value creation is dependent on the firm's ability to innovate successfully (Adner and Kapoor, 2010). It starts from the unique knowledge it has based on its history and experience in an industrial field. This knowledge is often embedded in its employees, routines and processes. Some of the knowledge that builds competitive advantage may be explicit and observable, in which case actively preserving exclusivity is of particular importance.

However, given that firms nowadays concentrate heavily on their core competences, they need to be outward looking in order to acquire the external knowledge they need to advance their innovative activities, and further to capture value. Innovations tend more and more to be based on collaboration, created and supported in innovation ecosystems. In fact, one of the main reasons why firms join forces is to gain access to external knowledge through collaborating with those that possess complementary knowledge (Hoecht and Trott, 2006; Inkpen and Crossan, 1995; Kale et al., 2000). The resulting knowledge spill-over from one partner to another is considered to be one of the primary explanations for the innovative success (Audretsch, 1995; Audretsch, 2002). Therefore, learning and internalising critical knowledge obtained from partners is a major activity in collaboration (Kale et al., 2000; Grant and Baden-Fuller, 2004), and is vital to the success of many firms. One challenging aspect is that the decision to share knowledge has to be made in cooperation with a variety of partners (Adner and Kapoor, 2010). Indeed, whereas a common aim in knowledge sharing between different entities is to create new knowledge and foster innovation, knowledge protection comes into play for two reasons. First, it allows the parties to safely join in the 
knowledge-sharing activities, and second, it may help to preserve the uniqueness of the outputs of knowledge exchange: the created new knowledge needs to have some sort of market value in order to benefit the inventors. This could create the need for a broader range of mechanisms in order to protect companies' specific knowledge within R\&D collaboration. It is not only a matter of capturing value from the created innovation, it is also important to share enough knowledge to create a common pie without losing one's core knowledge.

Thus, despite its advantages, knowledge sharing may involve certain risks for the partners particularly related to retaining core knowledge and capturing value: if core knowledge is lost, the value created by the collaboration may be overshadowed by the damage caused (Heiman and Nickerson, 2004). Being able to reap the benefits of innovativeness makes the difference in terms of gaining competitive advantage (Pisano and Teece, 2007). Therefore, firms should know how to capture the value emanating from collaboration in order to benefit individually from the knowledge sharing.

Given the ever-present risk in inter-firm collaboration, there is a need for different knowledgeprotection mechanisms - both formal and informal - to avoid the appropriation of existing valuable knowledge by someone else, or the rapid and wide diffusion of the innovation. The choice between different governance mechanisms depends on several issues, such as availability, the size of the firm and the industrial field in which it operates (see, e.g., Hall et al. 2012). We also argue that firms will choose different mechanisms for different situations, at least to some extent depending on their aims and needs with regard to protection: some situations may be more amenable to the use of more formal mechanisms of protection and appropriation, and others to the use of informal mechanisms. 


\subsection{Formal protection mechanisms}

The most commonly used formal mechanisms for preventing knowledge losses and protecting innovations are intellectual property rights (IPRs) and contracts. IPRs, such as patents, trademarks, copyright and trade secrets and contracts enable firms to hold on to their original creations and delay their imitation. Contracts covering the terms of the collaboration can be supported by employee-related non-disclosure agreements and non-competition agreements. IPRs allow for safe knowledge sharing in R\&D collaboration, and thus for the desired outcome (Hertzfeld et al., 2006). Likewise, a firm's existing patent pool may help to attract the attention of a potential collaboration partner, for instance.

The downside to these formal protection mechanisms is that they may be difficult to obtain. Consequently, not all of them are necessarily available to the firm (Hurmelinna-Laukkanen, 2009). More precisely, availability means that the innovation is protectable by formal means, and that the firm is able to file for and enforce the rights. Acquiring patent protection, for example, requires a complicated and relatively lengthy process of research, application and correspondence. Although patents are among the most frequently used mechanisms for protecting technological innovation, their efficacy has been questioned (Davis, 2004; Dosi et al., 2006; Kingston, 2001). Problems may arise especially in multinational R\&D collaboration because of the lack of harmonisation across national IPR systems that could allow misuse of the partner's innovation, for instance (Hertzfeld et $a l ., 2006)$. In any case, only new products that are substantially different from previous ones can be patented, which disqualifies many valuable innovations. Moreover, even if patenting is possible, it is costly and entails releasing information about the innovation: once a patent has been filed, the information is public and anyone can see what kind of products the firm is working on (this signal effect may also be positive, of course, but there are still risks) (e.g., Somaya, 2003). The patent application will disclose enough detail about the innovation to enable a competitor to copy and develop it further (Merges et al., 2003). Because of the resources required, it is only worthwhile obtaining a patent for the innovation if the firm has the ability and the means to detect 
infringements and act accordingly. The availability of other IPRs is similarly limited in that copyright protection is granted only to original creations, and trademark protection may be unavailable because of absolute and relative restrictions on registration.

There are also "darker sides" to other formal mechanisms. It has been argued that the excessive use of contracts between partners could be perceived as a sign of distrust, and could therefore have a negative effect on the willingness to share knowledge (Macaulay, 1963; Malhotra and Murnighan, 2002). This may be the case especially in industries in which the organisational culture and the way of doing things call for more informal approaches. Referring heavily and frequently to employer's rights based on employment contracts might have similar effects within the firm's boundaries. Likewise, non-disclosure agreements made with the firm's own employees may, on the one hand, help to protect its core knowledge by raising their awareness of their responsibilities, but on the other hand the fear of violating the non-disclosure agreement by divulging company secrets may discourage them from sharing any knowledge. Without sufficient knowledge sharing it is impossible to realise the potential that resides in the knowledge bases of the partnering firms, which would have a detrimental effect on innovativeness and the success of the collaborative endeavour (Dhanaraj and Parkhe, 2006). Nevertheless, it cannot be completely ruled out that the use of contracts in collaboration may even enhance trust building (Blomqvist et al., 2005; Burchell and Wilkinson, 1997; Klein Woolthuis et al., 2005), and thus positively affect performance. The important thing is to use formal arrangements to support efficient knowledge sharing rather than to limit it (Möller and Svahn, 2006; O’Neill and Adya, 2007).

As stated above, not all innovations are patentable, but if the innovation in question is, and if the firm has enforcing and monitoring capacity, we argue that patenting is likely. Similarly in the case of contracts, if the firm is able to write good contracts that clear the ground and make the responsibilities of each party explicit, and then to monitor for breaches, then contracting is likely. Thus, considering the possibilities of the firm and the benefits that formal protection can offer in R\&D collaboration, we put forward the following hypothesis: 
Hypothesis 1: There is a positive relationship between the availability of formal mechanisms and the use of formal protection.

In the collaboration context, formal means of protection may be used to decrease uncertainty related to the future. Contracts enable firms to prepare for different eventualities, such as opportunism, technical development or a take-over (Klein Woolthuis et al., 2005). Appropriately used, formal means can reduce the fear of opportunism in that the partners may feel more relaxed if there are ground rules covering the collaboration, and thus be more willing to share their knowledge. Existing patents in the same area and the use of non-disclosure agreements may have the same enhancing effect on the willingness to share knowledge because each partner's inventions are protected. It is easier to detect which rights belong to each of the partners when there are patents protecting the background knowledge. This could reduce the need for time-consuming negotiations about rights, and prevent unwanted disputes in unclear situations. On the assumption that knowledge sharing is easier if there is a clear system based on ground rules (e.g., contracts), and that collaboration can be more easily handled and managed if there are explicit boundaries distinguishing the partners' knowledge bases (e.g., patents), we hypothesise the following:

Hypothesis 2: There is a positive relationship between the need to make collaboration more manageable and safer, and the use of formal protection. 


\subsection{Informal protection mechanisms}

As noted above, there is a considerable amount of knowledge that remains unprotected by legal, institutionally established means, and for which more informal protection might be the most efficient alternative. This is especially the case when the invention does not meet IPR criteria. Furthermore, legal remedies tend to be too slow and too costly to effectively protect innovations in technology-intensive industries with a high rate of new inventions, (Deakin and Wilkinson, 1998; Liebeskind and Oliver, 1998).

A lot of valuable knowledge may remain without adequate formal protection. For example, IPRs cannot cover tacit knowledge in that it is difficult to obtain legal protection over something that cannot be seen or codified. However, the very nature of tacit knowledge, which does not transfer easily, inherently protects the know-how of the firm (Norman, 2002). The risk of knowledge leak is considerably smaller than with codified data, and thus the need for formal protection is lower (Contractor and Ra, 2002).

Tacit knowledge often resides in the firm's employees, and it has been noted in several studies that employees have a major role in knowledge transfer between firms (Cohen and Levinthal, 1990; Edvardsson, 2008; Minbaeva, 2005). Still, HRM as a mechanism for governing knowledge flows and protecting knowledge is rarely considered (for an exception, see Hurmelinna-Laukkanen and Puumalainen, 2007). HRM-related protection is founded on labour legislation, as it sets the ground rules for the employee-employer relationship and determines some of the rights and responsibilities of each party ${ }^{1}$. Nevertheless, such protection is still strongly informal in nature, and covers practical issues such as minimising personnel turnover, increasing employee commitment, and offering further training, career advancement and other perks.

Secrecy (or practical concealment) is another informal mechanism for protecting the firm's core knowledge (Hurmelinna-Laukkanen and Puumalainen, 2007). Forms of secrecy include sharing knowledge with only a few people in the first place, restricting client and partner access to certain 
areas in the firm's premises, keeping doors locked, and allowing only password access to computers and electronic files. (Some of) these measures may form the basis of formal, legal tradesecret protection, but secrecy still constitutes a distinctive appropriability mechanism.

Although informal and formal mechanisms could easily be seen as substitutes (e.g., secrecy or tacitness vs. patenting), they may also be complementary (e.g., IPRs and lead time). As mentioned above, formal protection is likely to be acquired whenever it is available. This does not mean, however, that such measures would be very effective in protecting different types of knowledge within the company. In fact, over-reliance on formal means may well lead to failure in terms of effectively regulating the outflow of skills (Baughn et al., 1997). Given such inefficiency (especially in protecting know-how that is embedded in the people), the complementary use of informal mechanisms is likely to provide additional security. Further, as a firm becomes used to using formal protection, it may not only appreciate the potential of informal means, but also find them easier to adopt. In line with this, we posit that:

Hypothesis 3: There is a positive relationship between the availability offormal mechanisms and the use of informal protection.

On the other hand, if formal protection is out of reach for technical reasons (see e.g., Lemley and Burk, 2003; Macdonald, 2004 on technology specifics in patent law), such as if it is too expensive and time-consuming to file for patents, or if the firm lacks the know-how or resources to acquire IPR protection and to draft contracts, it may be more willing to rely on more informal protection. In any case it is likely to possess knowledge that is vital for its competitiveness, and will at least try to keep it hidden by informal means.

Hypothesis 4: There is a positive relationship between the inconvenience of formal mechanisms and the use of informal protection. 
Olander et al. (2009) found that SMEs in particular tend to need protection in order to preserve the prerequisites for innovation rather than to safeguard innovative output. Together with the lack of resources, this makes SMEs turn to more informal means. We believe that such prerequisites for innovation are also important in larger firms, and that informal protection would be suitable for them as well. The prerequisites are often tacit in nature, including the knowledge embodied in the key personnel and their presence within the firm, their expertise and their know-how, and it is difficult to protect them by formal means. Moreover, some firms may not wish to use patent protection, which clearly communicates what the invention is about and gives competitors an indication of where they are going with their business (e.g., Somaya, 2003). Similarly, other formal protection may attract the competitors' interest in the invention more than the firm would wish. Sometimes it is best not to divulge ideas and inventions publicly, and to concentrate on preserving the prerequisites.

Hypothesis 5: There is a positive relationship between preserving the prerequisites for innovation and the use of informal protection.

Figure 1 below summarises the model that is tested in the study.

Insert Figure 1 about here 


\section{Research design}

\subsection{Sample and data collection}

We tested the hypotheses on survey data collected in Finland in 2008-2009 by means of a structured questionnaire, using the key-informant technique. The initial population comprised a cross-industry sample of Finnish companies engaged in R\&D that included all firms with at least 100 employees. The Amadeus database was used in identifying the companies. A total of 762 firms were considered suitable for the initial sample. The inclusion criterion (in addition to the number of employees) was that the firm should have on-going R\&D and innovation activity, and could affect such activity independently (i.e. subsidiaries and branches were excluded if they did not have such authority). All the eligible firms were contacted by telephone and were asked to participate in the study. Confidentiality was emphasised and a summary of the results was promised to the respondents. Of the R\&D representatives in the 762 firms 570 were reached after several contact attempts: it is possible that due to the time lag between accessing the contact information and making contact some of the companies had merged or ceased to exist. Of those contacted, 455 agreed to participate and 115 refused on the phone or when they received the questionnaire. The questionnaire was web-based, and each respondent received a personal link to it. Responses were received from 209 companies, representing a fairly satisfactory effective response rate of 36.7 per cent (209/570). Most of the respondents held positions such as chief executive officer, managing director, R\&D manager, or development officer, indicating their seniority and key position in terms of $\mathrm{R} \& \mathrm{D}$ and innovation.

\subsection{Measures}

Independent variables. Our independent variables were adopted and modified from the Hurmelinna-Laukkanen and Puumalainen (2007) study. The measures for the motivation and 
prerequisites for the use of protection mechanisms were constructed from responses to the question: "To what extent do the following statements characterise the protection of innovations in your company?" The respondents rated nine items on a seven-point Likert scale $(1=$ totally disagree, $7=$ totally agree). The items covered the availability of protection ( 2 items), the safety/manageability of protection ( 3 items), the inconvenience of protection (2 items) and preservation of the prerequisites for innovation ( 2 items). Appendix 1 shows the wording of the items.

Dependent variables. Formal and informal protection were covered by asking the respondents to assess the strength of the mechanisms they used in order to protect the firm's own innovations: "During the last three years, how well have the following mechanisms protected your innovations (products, services, processes) from imitation by competitors?" A list of 18 mechanisms followed and the respondents rated these on a seven-point Likert scale (1=not applicable to our innovations, 2=poorly, 7=very well). The study conducted by Hurmelinna-Laukkanen and Puumalainen (2007) and the Carnegie-Mellon Survey on industrial R\&D (see e.g., Cohen et al., 2002) were used in the item-development phase. The items for formal protection covered IPRs ( 3 items) and contracts (2 items). The items for informal protection concerned HRM (3 items), tacitness ( 7 items), and secrecy ( 3 items). See Appendix 1 for the wording of the items.

Control variables. Three variables (firm age, turnover and personnel) were used as control variables in order to eliminate whatever effects they might have had on the selected protection mechanisms. Firm age was measured in terms of years since establishment. Turnover was measured in 1000 euros, and personnel as the number of employees. 


\subsection{Assessment of bias}

The data relied on self-report measures, and therefore common method variance might have biased the findings. Common method bias is of particular concern when survey respondents are asked to fill out items covering both independent and dependent variables. We used Harman's one-factor test (Podsakoff et al., 2003) in order to assess the risk of such bias, and conducted a principal component analysis that incorporated all the items from all of the constructs. We investigated the solution in order to determine the number of factors required to account for the variance in all the items. The largest factor accounted for 16.5 per cent, which suggests that common method bias was not a concern.

\section{Results}

We used Partial Least Squares (PLS) for the analyses (version 2.0M3 of SmartPLS). The first step was to assess the reliability and validity of the measurement models. We then used the structural model to test our hypotheses.

\subsection{Correlation analysis}

Table 1 presents the means and standard deviations, and provides a correlation matrix.

As the matrix shows, there are significant correlations between the independent variables (i.e. the motivation and prerequisites for the use of protection mechanisms) and the dependent variables (i.e. formal and informal mechanisms). This indicates and supports our expectations of interconnectedness between motives and prerequisites and the selection of the protection mechanism. 
Insert Table 1 about here

\subsection{Measurement models}

In order to test the measurement models we assessed the internal consistency as well as the discriminant validity.

Internal consistency. Measures of construct reliability (CR) and convergent validity represent internal consistency. According to the CR test, all the constructs showed a value above the threshold (0.7, adopted by Bagozzi an Yi, 1988) (see Appendix 1). In order to test for convergent validity we examined CR, the factor loading and Average Variance Extracted (AVE). Firstly, the loadings of all the items were high and statistically significant (see Appendix 1). This means that they were all related to their specific constructs, verifying the posited relationships among the indicators and constructs. Secondly, the AVE measure exceeded the cut-off $(0.50$, see e.g., Fornell and Larcker, 1981) in most of our constructs. However, it fell short for informal protection, but when all the criteria for convergent validity are taken into account this measure is also applicable.

Discriminant validity. This indicates the extent to which any one construct differs from the others, and in assessing it the AVE should be greater than the variance shared between that construct and the other constructs in the model (i.e. the squared correlation between two constructs) (Fornell and Larcker, 1981). The constructs of our study fulfil this condition: in our three models (see Tables 2-4) the diagonal elements (AVEs) are greater than the off-diagonal elements in the corresponding rows and columns. 
In sum, the model assessments gave good evidence of validity and reliability for the operationalization of the concepts.

Insert Table 2 about here

Insert Table 3 about here

Insert Table 4 about here

\subsection{Testing the research model}

As Table 5 shows, our research model could explain 41 and 24 per cent of the variance in formal and informal protection, respectively.

We estimated the path model reflecting the posited relationships between the motivation and the prerequisites for using protection mechanisms and the selected mechanism in order to test the hypotheses. The path estimates from the availability (H1) and the safety/manageability (H2) of protection towards formal protection were as hypothesised. Availability $(\mathrm{B}=0.351, \mathrm{p}<0.005)$ and 
safety/manageability $(B=0.300, p<0.005)$ each had a significant, positive impact on the selection of formal protection. Our research model also predicts direct paths from the availability (H3) and the inconvenience $(\mathrm{H} 4)$ of protection and the preservation of the prerequisites for innovation $(\mathrm{H} 5)$ to informal protection mechanisms. As expected, the effects of availability $(B=0.326, p<0.005)$ inconvenience $(B=0.127, p<0.05)$, and the preservation of the prerequisites $(B=0.243, p<0.005)$ on informal protection were all significant and in the predicted direction.

In addition, to assess the generalizability of our findings we tested whether our hypotheses still held in companies with different innovation types and in different industries. For this purpose we divided our sample into sub-samples. First, we categorised companies according to the orientation of their innovation activities as 1) radical and 2) incremental. Second, acknowledging that companies operating in some industries may rely heavily on formal protection and others on informal protection, we classified our sample by industry as 3) formal-protection oriented (e.g., wood and paper, and chemical products manufacturing) and 4) informal-protection oriented (e.g. services). Most of our hypotheses held within all of the aforementioned sub-samples. Of the 20 path estimates we tested 17 were statistically significant. Those for H1 in one sub-sample (radical innovation) and for $\mathrm{H} 4$ in two sub-samples (radical innovation and informal protection) were not statistically significant however, but in line with the methodological literature (see e.g., Hair et al., 2006) we believe this could be related to the small size of our sub-samples (16 companies for radical innovation and 39 for informal protection). We argue that the generalizability of our findings to the different sub-samples indicates that they hold for many kinds of R\&D-intensive firms. 
4.4 Testing the models related to formal and informal mechanisms

In addition to testing our research model we wanted to explore the relationships between the motivation and prerequisites for using protection mechanisms and the selected mechanisms in more detail. Thus we tested two additional models, one including the two formal mechanisms (IPR and contracts) separately and one with the three informal mechanisms (HRM, secrecy and tacitness) separately.

As Table 6 shows, the model including two formal mechanisms explains 41 and 14 per cent of the selection of IPRs and contracts, respectively. Path estimates from the availability of protection to IPR $(B=0.375, p<0.005)$ and contracts $(0.138, \mathrm{p}<0.10)$ show a relationship between availability and the selection of both mechanisms. The safety and manageability of the collaboration also affect the selection of both (IPRs: $\mathrm{B}=0.259, \mathrm{p}<0.005$; contracts: $\mathrm{B}=0.251, \mathrm{p}<0.005$ ).

It can be seen from Table 7 that the model for the three informal mechanisms explains 20 per cent of the selection of HRM, 14 per cent of tacitness, and 18 per cent of secrecy. Moreover, the path estimates reveal a connection between the availability of formal protection and the use of HRM $(B=0.272, p<0.005)$, tacitness $(B=0.225, p<0.005)$ and secrecy $(B=0.306, p<0.005)$ as informal mechanisms.

In addition, preservation of the prerequisites for innovation and $\operatorname{HRM}(B=0.245, \mathrm{p}<0.005)$, tacitness $(B=0.163, p<0.05)$ and secrecy $(B=0.192, p<0.005)$ were strongly interconnected. Interestingly, in the relationship between the inconvenience of formal protection and the three informal mechanisms only one (tacitness) showed any connection $(B=0.146, p<0.05)$, and there was no statistically significant relationship with the other two, HRM $(B=0.042, p>0.10)$ and secrecy $(B=0.058, \mathrm{p}>0.10)$. These results are discussed in more detail in the following section. 


\section{Discussion}

In this study we developed and tested five hypotheses. The first two (Hypotheses 1 and 2) concerned the motivation and prerequisites for the use of formal protection mechanisms. The second set (Hypotheses 3-5) examined the motivation to rely on informal mechanisms. Table 8 summarises the results.

Insert Table 8 about here

The findings from our study of 209 large R\&D-intensive firms in Finland validated all of our hypotheses. According to our analysis, the empirical data supports Hypothesis 1 (There is a positive relationship between the availability of formal mechanisms and the use of formal protection). In other words, if it is possible for firms to protect their intellectual assets (knowledge and innovations) by formal means, they are inclined to do so. Formal protection is a must in many industries nowadays, which explains this tendency along with the increase in strategic positioning. We found in our further investigation of the model including two formal mechanisms that the availability of protection was strongly connected to choosing IPRs, but not as strongly connected to choosing contracts. In industries in which the availability of IPR protection is established it is indeed a must for achieving lead time and generating revenue from innovations. The firms concerned probably tend to collaborate with other firms, but the results suggest that they may, to a certain extent, do so informally and not based on explicit contracts. In accordance with our Hypothesis 2 (There is a positive relationship between the need to make collaboration more manageable and safer, and the use of formal protection), formal mechanisms were actively used when the safe transfer of knowledge was a necessity and intellectual assets needed to be in a more 
manageable form. In our further investigation we found that the safety and manageability of collaboration as a reason for choosing protection mechanisms was significantly related to both IPRs and contracts. This is understandable, as in many cases IPRs are used to prevent imitation, and contracts then allow the transferring of these rights (e.g., licensing agreements). Moreover, contracts can cover any related knowledge that is not IPR-protected but needs to be transferred.

However, even if formal protection is available and is used, firms also rely on informal mechanisms. The evidence supporting Hypothesis 3 (There is a positive relationship between the availability of formal mechanisms and the use of informal protection) backs this statement. One explanation could be that formal protection cannot cover all of the uncertainties related to the future, and does not extensively cover the role of human resources in keeping knowledge protected. Furthermore, acquiring formal protection calls for an analytical approach in terms of identifying the intellectual assets to be protected and finding the suitable mechanisms, which also may lead to an increase in the use of informal means. Indeed, further analysis of the model including the three informal mechanisms (HRM, tacitness and secrecy) showed that all were important, even if formal protection was available.

The data also supports Hypothesis 4 (There is a positive relationship between the inconvenience of formal mechanisms and the use of informal protection). The implication is that every firm needs some sort of protection, and if formal means are out of reach, informal protection is a viable alternative. However, the path coefficient was lower than in the other hypotheses $(B=0.127, p<$ 0.05). A plausible explanation is that in our further analysis we found tacitness to be the only variable significantly related to inconvenience: if a company finds formal protection expensive and difficult, it relies on tacitness over HRM and secrecy. Even though these two are informal in nature, they require effort, legal knowledge and company resources to be properly implemented. In fact, it may be that relying on informal mechanisms when formal ones are not deemed usable may not be a conscious choice, and that in the absence of formal protection the firm only relies on tacitness because it happens to protect its intellectual assets. Finally, there was support for Hypothesis 5 
(There is a positive relationship between the preservation of the prerequisites for innovation and the use of informal protection). Firms relying on informal means of protection do not have to codify or publish knowledge that allows them to be innovative. Further analysis suggested that HRM and secrecy in particular are significantly related to the safety of innovation prerequisites, whereas tacitness seemed to play a less significant role. Protecting the prerequisites appears to be an active effort. HRM-related protection can be used actively to enhance employee awareness of core knowledge requirements and to commit key people to the company. Likewise, applying secrecy supports the protection of the prerequisites in showing what knowledge is deemed relevant and by limiting knowledge sharing outside the firm. Although tacitness does protect firm-specific knowledge, it may also have adverse effects in terms of preserving innovativeness, such as if knowledgeable employees are laid off and the knowledge is embedded in people and not in routines.

In addition, we found support for the generalizability of our findings. Our hypotheses seem to hold regardless of whether the orientation of the innovation activities was radical or incremental, or whether the industry was oriented to formal or informal protection.

In sum, it seems that firms having access to formal protection also know how to use informal protection mechanisms as a complementary measure. On the other hand, firms that find formal protection inconvenient are in the least favourable position: they may not know how to use informal mechanisms either, they might not have the resources to use formal or informal mechanisms, or they simply may not recognise the informal mechanisms (apart from tacitness) as protection devices. 


\section{Conclusions}

This study examined the reasons behind firms' choices regarding the use of formal and informal mechanisms in protecting their knowledge and innovations. The findings advance the research on the protection of knowledge and intellectual assets, as well as on profiting from innovations. We contribute to the literature with our quantitative analysis of the relationship between the recognised need for protection and the choice of formal governance as a strategy. Second, we address both formal and informal mechanisms, as well as their interconnections. Third, to the best of our knowledge this is one of the few studies examining HRM-related protection mechanisms.

Previous studies provided us with a starting point from which to evaluate the different forms of protection. In terms of formal mechanisms our results are in line with those reported in earlier research. The use of formal governance in the form of contracts and IPRs may make collaboration and the innovations related to it easier to manage (Kuivalainen et al. 2003), and help in preparing for future uncertainties (Klein Woolthuis et al., 2005). If formal protection is available it will be used to some extent because it is beneficial to collaborating partners and, in some cases, necessary because of the pressures related to its use in the industry concerned: if it is in active use other firms need to follow suit in order to avoid infringement claims and preserve their operational freedom.

Our findings on the use of informal protection differ from those reported in previous studies. The use of informal mechanisms is frequently associated with the lack of resources to acquire formal protection, which in turn tends to be related to the size of the firm (Kitching and Blackburn 1999; Leiponen and Byma, 2009). Likewise, it seems that the nature of the industry plays a role in that it may not be very easy to apply formal means of protection to services, for example (Blind et al., 2003; Maskus, 2008). We have taken these issues into account but do not focus on them. Instead, we examine the role of formal mechanisms, and especially their use, with respect to reliance on informal mechanisms, and consider the need to preserve the prerequisites of innovation as a reason for choosing informal protection. With regard to the prerequisites the results were in 
accordance with the findings of Olander et al. (2009). However, whereas the SMEs in their study were more concerned about protecting the prerequisites than the innovative output, our results suggest that larger firms may also value informal mechanisms. Formal protection alone cannot cover all future uncertainties (Gulati, 1995; Poppo and Zenger, 2002) and, especially with regard to IPRs and their availability, is strongly industry-dependent. For example, patent law is uniform and technology-neutral in theory, but in terms of application it is technology-specific (Lemley and Burk, 2003). Indeed, our results rather strongly support the use of informal protection, especially in conjunction with formal mechanisms when available. Subsequently, its role in large firms may be more significant than previously thought. It has been noted that large firms may prefer formal means given that they are capable of using them on account of their ample resources and expertise (e.g., Olander et al., 2009). However, when the focus changes from protecting the outcomes of the innovation process to protecting the prerequisites, informal means become more relevant.

Furthermore, formal protection makes sources of innovation more visible (Somaya, 2003), in which case the use of informal HRM-related mechanisms may be a better choice in order to mitigate risks.

The study provides managers with useful information on the informal governance of knowledge and innovations in collaboration. First, regarding formal protection, managers should carefully evaluate the implications related to availability. If such protection is easily accessible it is likely that firms operating in the same markets and business environment utilize it. In such a situation neglecting to do so may result in the firm not being able to respond efficiently to infringement claims or the actions of other organisations, thus jeopardising operational freedom. Managers also need to consider the need for the firm to engage in collaborative endeavours, both at present and in the future. It is very difficult to start protecting firm-specific intellectual assets once they have already been made available to partners, or their value has become visible.

With regard to informal protection, acquiring efficient means seems to require conscious effort. First, it seems that companies acquiring formal protection are also better at utilising informal protection: such firms need to analyse carefully their intellectual assets and potential objects of 
protection, and this also supports the establishment of informal mechanisms in a more structured manner. The same conclusion can be drawn from our finding suggesting that firms finding formal protection problematic only benefit from the informal protection tacit knowledge provides. Controlling for the presence of tacitness is quite hard (Hurmelinna-Laukkanen and Puumalainen, 2007), and it may be that rather than providing planned and intentional protection, it comes into play when all other forms fail. The need for explicit intent also shows in our finding that HRM and secrecy play a bigger role than tacitness among firms that are concerned about protecting the prerequisites for innovation. Informal mechanisms seem particularly relevant when the prerequisites rather than the output of innovation need to be protected. Consequently, managers should allocate more resources to the active use of informal mechanisms when the firm is heavily dependent on its existing knowledge to create future innovations. This means, for example, securing employee commitment when the firm is dependent on key projects and key people. It also means preventing unwanted knowledge leaks in $R \& D$ collaboration by educating employees who are at the collaboration interface on how to deal with confidential knowledge on the one hand, for example, and on the other hand limiting access to such critical knowledge in the first place.

In sum, firms should not only consider protection issues, they also need to design an entire appropriability strategy that goes beyond patenting and takes other related matters into account. In particular, resource allocation is more efficient when formal and informal appropriability mechanisms are carefully evaluated in the light of the firm's business environment and innovation activities. All units should collaborate in this process. Firms engaging in R\&D collaboration may also benefit from the findings of this study in terms of learning from the motives of their partners in their use of different mechanisms.

As in any study, there are limitations to this one. The data was gathered in a single country, Finland, which may have affected the results: the legal system is known for its efficiency, for example, which could perhaps enhance the companies' reliance on formal protection. The results and the different emphases on formal and informal protection may be different if practices in a 
culture based more on informal relations and with a less efficient patent system (e.g., Russia, China) were investigated. This could be an interesting path for further studies. However, we conclude from our aforementioned tests on four sub-samples that our results are generalizable to different kinds of companies, and to other Western countries with similar legal systems as well. Furthermore, we consider Finland a reliable setting in which to examine knowledge-related abstract phenomena in the first place. As a small economy and a fairly homogenous country culturally and economically, it should be a good setting in which to measure knowledge-based variables that tend to be abstract: homogeneity reduces the likelihood of culturally interpreted variation in the perception of abstract constructs (Spender and Grant, 1996, Autio et al., 2000). Finally, although we considered the effects of size, industry and innovation type in order to enhance the generalizability of our findings, future studies could still consider these issues in more detail. The work done in this study and its limitations provide the basis for such research. 


\section{References and notes}

Adner, R. and Kapoor, R. (2010), "Value creation in innovation ecosystems: How the structure of technological interdependence affects firm performance in new technology generations", Strategic Management Journal, Vol. 31, pp. 306-33.

Arundel, A. (2001), "The relative effectiveness of patents and secrecy for appropriation", Research Policy, Vol. 30, pp. 611-24.

Audretsch, D.B. (1995), Innovation and industry evolution, Cambridge, Massachusetts: MIT Press.

Audretsch, D.B. (2002), "The dynamic role of small firms: Evidence from the U.S.", Small Business Economics, Vol. 18, pp. 13-40.

Autio E., Sapienza, H.J. and Almeida, J.G. (2000), "Effects of age at entry, knowledge intensity, and imitability on international growth", Academy of Management Journal, Vol. 43 No. 5, pp. 90924.

Bader, M.A. (2008), "Managing intellectual property in inter-firm R\&D collaborations in knowledge-intensive industries", International Journal of Technology Management, Vol. 41 No. 3/4, pp. 311-35.

Bagozzi, R. P. and Yi, Y. (1991), "Multitrait-Multimethod Matrices in Consumer Research", Journal of Consumer Research, Vol. 17 No 4, pp. 426-39.

Baughn, C.C., Stevens, J.H., Denekamp, J.G. and Osborn, R.N. (1997), "Protecting intellectual capital in international alliances", Journal of World Business, Vol. 32 No. 2, pp. 103-17.

Blind, K., J. Edler, U. Schomch, B. Anderson, H. Howells, I. Miles, J. Roberts, L. Green, R.

Evangelista, C. Hipp and Herstatt, C. (2003). Patents in the service industries, Final report, Karlsruhe, Germany: FhG-ISI. 
Blomqvist, K., Hurmelinna, P. and Seppänen, R. (2005), "Playing the collaboration game right Balancing trust and contracting", Technovation, Vol. 25, pp. 497-504.

Burchell, B. and Wilkinson, F. (1997), "Trust, business relationships and the contractual environment", Cambridge Journal of Economics, Vol. 21, pp. 217-37.

Cohen, W.M. and Levinthal, D.A. (1990), "Absorptive capacity: A new perspective on learning and innovation", Administrative Science Quarterly, Vol. 35 No. 1, pp. 128-52.

Cohen, W.M., Nelson, R.R. and Walsh, J.P. (2000), "Protecting their intellectual assets:

Appropriability conditions and why US manufacturing firms patent (or not)", Working paper 7552, National Bureau of Economic Research, Inc.

Cohen, W.M., Nelson, R.R. and Walsh, J.P. (2002), "Links and Impacts: The Influence of Public Research on Industrial R\&D", Management Science, Vol. 48 No. 1, pp. 1-23.

Contractor, F.J. and Ra, W. (2002), "How knowledge attributes influence alliance governance choices: a theory development note", Journal of International Management, Vol. 8, pp. 11-27.

Davis, L. (2004), "Intellectual property rights, strategy and policy", Economics of innovation and new technology, Vol. 13 No. 5, pp. 399-415.

Deakin, S. and Wilkinson, F. (1998), "Contract law and the earning of inter-organizational trust", in Lane, C. and Bachmann, R. (Eds.), Trust Within and Between Organizations, Oxford: Oxford University Press, pp. 146-72.

Dhanaraj, C. and Parkhe, A. (2006), "Orchestrating innovation networks", Academy of Management Review, Vol. 31, No. 3, pp.659-69.

Dosi, G., Malerba, F., Ramello, G.B. and Silva, F. (2006), "Information, appropriability, and the generation of innovative knowledge four decades after Arrow and Nelson: An introduction", Industrial and Corporate Change, Vol. 15 No. 6, pp. 891-901. 
Edvardsson, I.R. (2008), "HRM and knowledge management" Employee Relations, Vol. 30, No. 5, pp. 553-61.

Fornell, C. and Larcker, D. F. (1981), "Evaluating Structural Equation Models with Unobservable Variables and Measurement Error", Journal of Marketing Research, Vol. 18 No. 1, pp. 39-50.

Galende, J. (2006), "The appropriation of the results of innovative activities", International Journal of Technology Management, Vol. 35 No. 1-4, pp. 107-35.

Gallié, E-P. and Legros, D. (2012). “French firms' strategies for protecting their intellectual property", Research Policy, Vol. 41, pp. 780-94.

Grant, R.M. and Baden-Fuller, C. (2004), "A knowledge accessing theory of strategic alliances", Journal of Management Studies, Vol. 41 No. 1, pp. 62-84.

Gulati, R. (1995), "Does familiarity breed trust? The implications of repeated ties for contractual choise in alliances", Academy of Management Journal, Vol. 38 No. 1, pp. 85-112.

Hall, B.H., Helmers, C., Rogers, M. and Sena, V. (2012), “The choice between formal and informal intellectual property: A literature review" Working Paper 17983, National Bureau Of Economic Research, Inc.

Hair, J. F., Black, W. C., Babin, B. J., Anderson, R. E., and Tatham, R. L. (2006), Multivariate Data Analysis - 6th edition, New Jersey: Pearson Education.

Heiman, B.A. and Nickerson, J.A. (2004). "Empirical evidence regarding the tension between knowledge sharing and knowledge expropriation in collaborations". Managerial and Decision Economics, Vol. 25 No. 6/7, pp. 401-20.

Hertzfeld, H.R., Link, A.N. and Vonortas, N.S. (2006), "Intellectual property protection mechanisms in research partnerships", Research Policy, Vol. 35, pp. 825-38.

Hoecht, A. and Trott, P. (2006), "Innovation risks of strategic outsourcing", Technovation, Vol 26, pp. 672-81. 
Hurmelinna-Laukkanen, P. (2009), "The availability, strength and efficiency of appropriability mechanisms in knowledge creation", International Journal of Technology Management, Vol. 45 No. $3 / 4$, pp. 282-90.

Hurmelinna-Laukkanen, P. and Puumalainen K. (2007), "The nature and dynamics of appropriability - Strategies for appropriating returns on innovation", R\&D Management, Vol. 37 No. 2, pp. 95-112.

Inkpen, A.C., Crossan, M.M. (1995), "Believing is seeing: joint ventures and organisational learning", Journal of Management Studies, Vol. 32 No.5, pp. 595-618.

Kale, P., Singh, H., and Perlmutter, H. (2000), "Learning and protection of proprietary assets in strategic alliances: Building relational capital", Strategic Management Journal, Vol. 21 No. 3, pp. 217-37.

Kingston, W. (2001), "Innovation needs patent reform", Research Policy, Vol. 30 No. 3, pp. 40323.

Kingston, W. (2006), "The limited incontestability for small-firm patents", European Intellectual Property Review, No. 9, pp. 462-67.

Kitching, J. and Blackburn, R. (1999). "Intellectual property management in the small and medium enterprise (SME)", Journal of Small Business and Enterprise Development, Vol. 5 No. 4, pp. 32735.

Klein Woolthuis, R., Hillebrand, B. and Nootebool, B. (2005), "Trust, contract and relationship development", Organization Studies, Vol. 26 No. 6, pp. 813-40.

Kuivalainen, O., Kyläheiko, K., Puumalainen K. and Saarenketo, S. (2003). "Knowledge-based view on internationalization: Finnish telecom software suppliers as an example", in Von Zedtwitz, M., Haour, G., Khalil, T. and Lefebvre, L. (Eds.), Management of Technology: Growth through Business, Innovation and Entrepreneurship, Oxford: Pergamon Press, pp. 239-64. 
Lang, J.C. (2001), "Management of intellectual property rights -Strategic patenting", Journal of Intellectual Capital, Vol. 2 No. 1, pp. 8-26.

Leiponen, A. and Byma, J. (2009), "If you cannot block, you better run: Small firms, cooperative innovation, and appropriation strategies", Research Policy, Vol. 38, 1478-88.

Lemley, M.A. and Burk, D.L. (2003), "Policy levers in patent law", Virginia Law Review, Vol. 89, pp. $1575-1650$.

Lieberman, M.B. and Montgomery, D.B. (1988), "First-mover advantages", Strategic Management Journal, Vol. 9, pp. 41-85.

Liebeskind, J. and Oliver, A. (1998), "From handshake to contract: Intellectual property, trust and the social structure of academic research", in Lane, C. and Bachmann, R. (Eds.), Trust Within and Between Organizations, Oxford: Oxford University Press, pp. 118-45.

Macaulay, S. (1963), "Non-contractual relations in business: a preliminary study", American Sociological Review, Vol. 28 No. 1, pp. 55-70.

MacDonald, S. (2004), "When means become ends: Considering the impact of patent strategy on innovation", Information Economics and Policy, Vol. 16, pp. 135-58.

Malhotra, D. and Murnighan, J.K. (2002), "The effects of contracts on interpersonal trust", Administrative Science Quarterly, Vol. 47 No. 3, pp. 534-59.

Maskus, K.E. (2008). "The globalization of intellectual property rights and innovation in services", Journal of Industry, Competition and Trade, Vol. 8, pp. 247-67.

Merges, R.P., Meell, P.S. and Lemley, M.A. (2003), Intellectual property in the new technological age - Third edition, Aspen publishers.

Minbaeva, D.B. (2005), "HRM practices and MNC knowledge transfer", Personnel Review, Vol. 34 No. 1, pp. 125-43. 
Möller, K. and Svahn, S. (2006), "Role of knowledge in value creation in business nets", Journal of Management Studies, Vol. 43 No. 5, pp. 985-1007.

Neuhäusler, P. (2012). "The use of patents and informal appropriation mechanismsm - Differences between sectors and among companies", Technovation, Vol. 32, 681-93.

Norman, P.M. (2002), "Protecting knowledge in strategic alliances, Resource and relational characteristics", Journal of High-Technology Management Research, Vol. 13 No. 2, pp. 177-202.

Olander, H., Hurmelinna-Laukkanen, P. and Mähönen, J. (2009), "What's small size got to do with it? Protection of intellectual assets in SMEs", International Journal of Innovation Management, Vol. 13 No. 3, pp. 349-70.

O’Neill, B.S. and Adya, M. (2007), "Knowledge sharing and the psychological contract, Managing knowledge workers across different stages of employment", Journal of Managerial Psychology, Vol. 22 No. 4, pp. 411-36.

Pisano, G.P. and Teece, D.J. (2007), "How to capture value from innovation: Shaping intellectual property and industry architecture", California Management review, Vol. 50 No. 1, pp. 278-94.

Podsakoff, P.M., MacKenzie, S.B., Lee, J.-Y. and Podsakoff, N.P. (2003), "Common Method Biases in Behavioral Research: A Critical Review of the Literature and Recommended Remedies", Journal of Applied Psychology, Vol. 88, pp. 879-903.

Poppo, L. and Zenger, T. (2002), "Do formal contracts and relational governance function as substitutes or complements?", Strategic Management Journal, Vol. 23 No. 8, pp. 707-25.

Porter, M.E. (1985), Competitive advantage: Creating and sustaining superior performance, Free Press, New York.

Reuer, J.J. and Ariño, A. (2005), "Contractual complexity in strategic alliances", Working paper, published 5/2005, 39 pages. 
Somaya, D. (2003), "Strategic determinants of decisions not to settle patent litigation", Strategic Management Journal, Vol. 24 No.1, pp. 17-38.

Spender, J.C. and Grant, R. (1996), "Knowledge and the firm: An overview", Strategic Management Journal, Vol. 17, pp. 3-9.

${ }^{1}$ (on page 9) In the authors' home country (Finland) the law related to employment (Employment Contracts Act) refers to the responsibilities of the employee, such as the legal loyalty principle, and to the rights of the employer, such as the legal right to assign tasks. 
Appendix 1: Measurement items

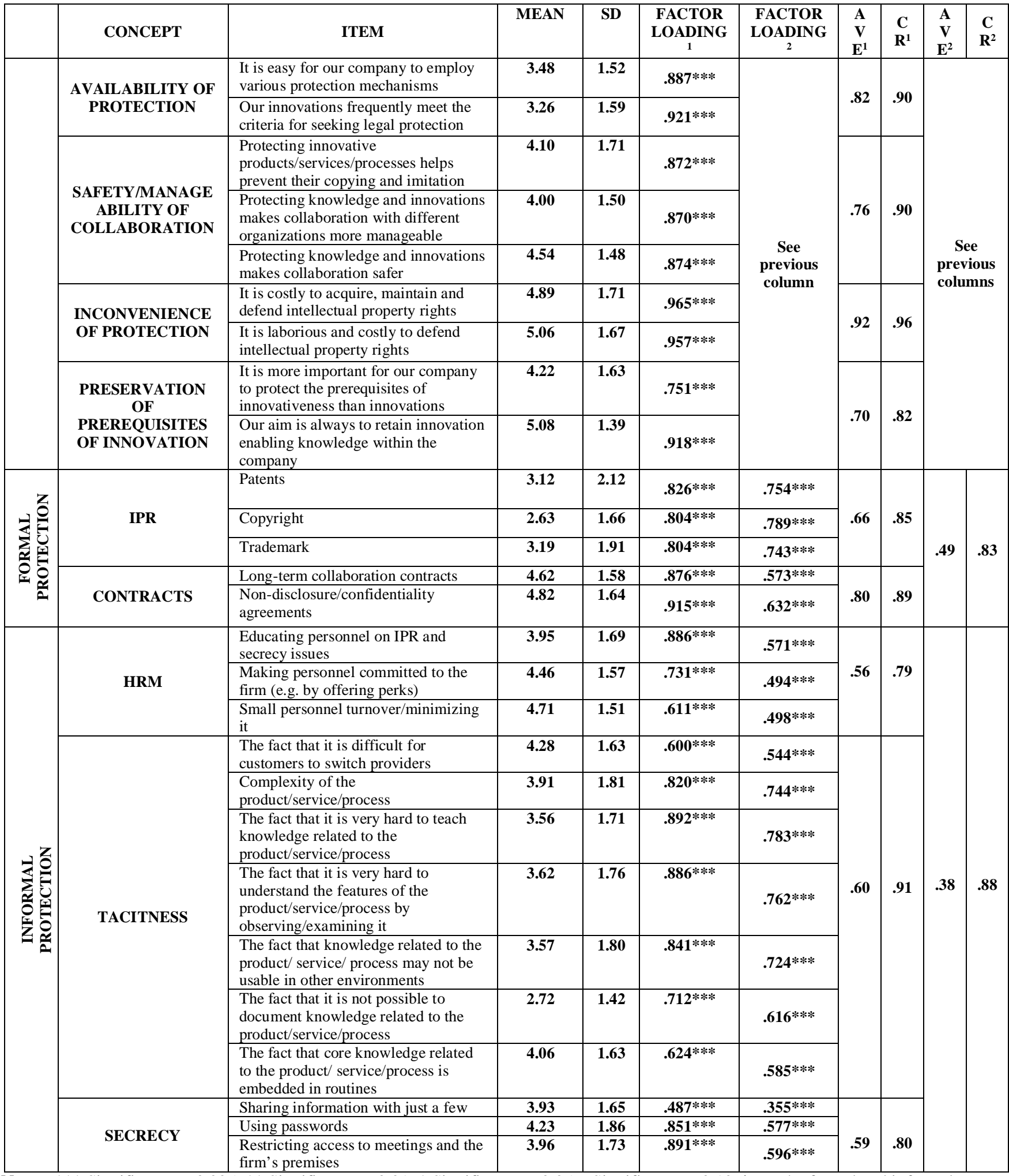

Notes: $* * *$ Significance $<0.005$; ** Significance $<0.01$; $*$ Significance $<0.05$; ${ }^{a}$ Significance $<0.10 .{ }^{1}$ For the formal and informal mechanism models. ${ }^{2}$ For the research model. 
Figure 1 The proposed model

The reasons for choosing the use

Protection mechanisms: of protection mechanisms:

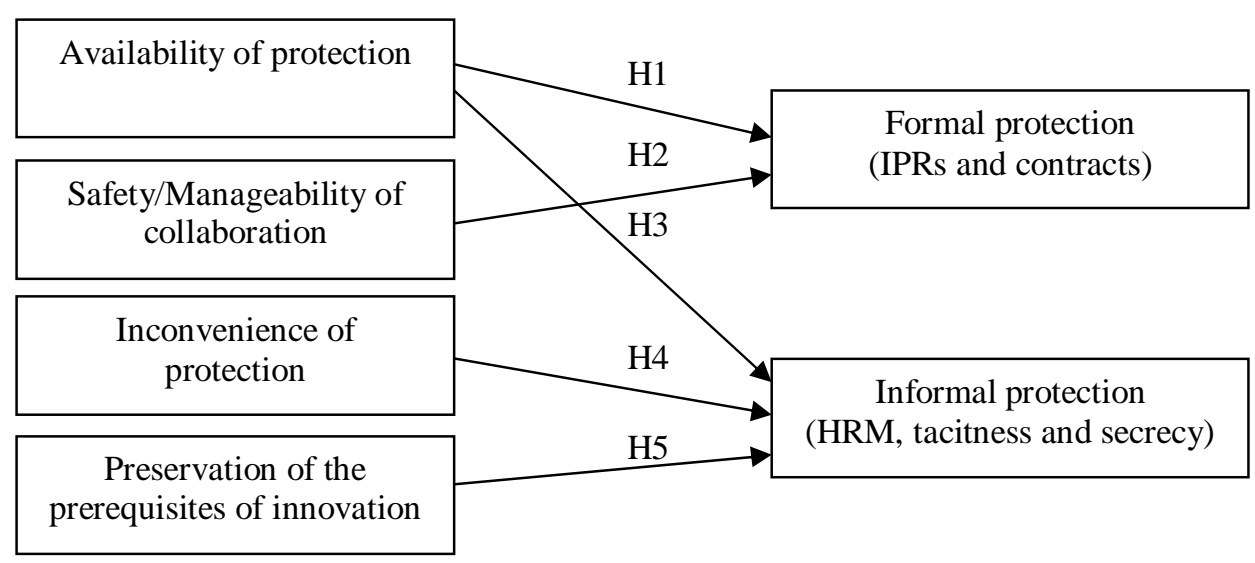


Table 1 Correlation matrix

\begin{tabular}{|c|c|c|c|c|c|c|c|}
\hline & Mean & $S D$ & 1 & 2 & 3 & 4 & 5 \\
\hline $\begin{array}{l}\text { 1. Availability of } \\
\text { protection }\end{array}$ & 3.37 & 1.41 & & & & & \\
\hline $\begin{array}{l}\text { 2. Safety/ } \\
\text { Manageability of } \\
\text { collaboration }\end{array}$ & 4.22 & 1.36 & $\begin{array}{l}0.501 \\
* *\end{array}$ & & & & \\
\hline $\begin{array}{l}\text { 3. Inconvenience } \\
\text { of protection }\end{array}$ & 4.98 & 1.62 & $0.139 *$ & $\begin{array}{c}0.249 \\
* *\end{array}$ & & & \\
\hline $\begin{array}{l}\text { 4. Preservation of } \\
\text { prerequisites of } \\
\text { innovation }\end{array}$ & 4.65 & 1.28 & $\begin{array}{c}0.248 \\
* *\end{array}$ & $0.138^{*}$ & 0.089 & & \\
\hline $\begin{array}{l}\text { 5. Formal } \\
\text { protection }\end{array}$ & 3.68 & 1.26 & $\begin{array}{c}0.497 \\
* *\end{array}$ & $\begin{array}{c}0.516 \\
* *\end{array}$ & $0.153 *$ & 0.105 & \\
\hline $\begin{array}{l}\text { 6. Informal } \\
\text { protection }\end{array}$ & 3.92 & 1.03 & $\begin{array}{c}0.358 \\
* *\end{array}$ & $\begin{array}{c}0.333 \\
* *\end{array}$ & $0.200 * *$ & $\begin{array}{c}0.290 \\
* *\end{array}$ & $\begin{array}{c}0.420 \\
* *\end{array}$ \\
\hline
\end{tabular}

Notes: ** Correlation is significant at the 0.01 level; * Correlation is significant at the 0.05 level

Table 2 Discriminant validity for the research model

\begin{tabular}{|c|c|c|c|c|c|c|}
\hline & 1 & 2 & 3 & 4 & 5 & 6 \\
\hline $\begin{array}{l}\text { 1. Availability of } \\
\text { protection }\end{array}$ & .82 & & & & & \\
\hline $\begin{array}{l}\text { 2. Safety/ } \\
\text { Manageability of } \\
\text { collaboration }\end{array}$ & .25 & .76 & & & & \\
\hline $\begin{array}{l}\text { 3. Inconvenience } \\
\text { of protection }\end{array}$ & .02 & .06 & .92 & & & \\
\hline $\begin{array}{l}\text { 4. Preservation of } \\
\text { prerequisites of } \\
\text { innovation }\end{array}$ & .06 & .02 & .01 & .70 & & \\
\hline $\begin{array}{l}\text { 5. Formal } \\
\text { protection }\end{array}$ & .25 & .27 & .02 & .01 & .49 & \\
\hline $\begin{array}{l}\text { 6. Informal } \\
\text { protection }\end{array}$ & .13 & .11 & .04 & .08 & .18 & .38 \\
\hline
\end{tabular}

Notes: AVE associated with the construct is presented diagonally.

The squared correlations between constructs are presented in the lower left triangle. 
Table 3 Discriminant validity for the formal mechanisms model

\begin{tabular}{|c|c|c|c|c|c|c|}
\hline & 1 & 2 & 3 & 4 & 5 & 6 \\
\hline $\begin{array}{l}\text { 1. Availability of } \\
\text { protection }\end{array}$ & .82 & & & & & \\
\hline $\begin{array}{l}\text { 2. Safety/ } \\
\text { Manageability of } \\
\text { collaboration }\end{array}$ & .25 & .76 & & & & \\
\hline $\begin{array}{l}\text { 3. Inconvenience } \\
\text { of protection }\end{array}$ & .02 & .06 & .92 & & & \\
\hline $\begin{array}{l}\text { 4. Preservation of } \\
\text { prerequisites of } \\
\text { innovation }\end{array}$ & .06 & .02 & .01 & .70 & & \\
\hline 5. IPR & .26 & .24 & .04 & .01 & .66 & \\
\hline 6. Contracts & .07 & .11 & .00 & .01 & .14 & .80 \\
\hline
\end{tabular}

Notes: AVE associated with the construct is presented diagonally.

The squared correlations between constructs are presented in the lower left triangle.

Table 4 Discriminant validity for the informal mechanisms model

\begin{tabular}{|c|c|c|c|c|c|c|c|}
\hline & 1 & 2 & 3 & 4 & 5 & 6 & 7 \\
\hline $\begin{array}{l}\text { 1. Availability of } \\
\text { protection }\end{array}$ & .82 & & & & & & \\
\hline $\begin{array}{l}\text { 2. Safety/ } \\
\text { Manageability of } \\
\text { collaboration }\end{array}$ & .25 & .76 & & & & & \\
\hline $\begin{array}{l}\text { 3. Inconvenience } \\
\text { of protection }\end{array}$ & .02 & .06 & .92 & & & & \\
\hline $\begin{array}{l}\text { 4. Preservation of } \\
\text { prerequisites of } \\
\text { innovation }\end{array}$ & .06 & .02 & .01 & .70 & & & \\
\hline $\begin{array}{l}\text { 5. Formal } \\
\text { protection }\end{array}$ & .07 & .10 & .01 & .08 & .56 & & \\
\hline 6. Tacitness & .07 & .04 & .04 & .04 & .16 & .60 & \\
\hline 7. Secrecy & .12 & .13 & .01 & .06 & .13 & .12 & .59 \\
\hline
\end{tabular}

Notes: AVE associated with the construct is presented diagonally.

The squared correlations between constructs are presented in the lower left triangle. 
Table 5 Results of testing for the research model

\begin{tabular}{|c|c|c|c|}
\hline Path & Path coefficient & t-value & $\mathrm{R}^{2}$ \\
\hline \multicolumn{4}{|l|}{ Control variables } \\
\hline Turnover $\rightarrow$ Formal protection & -.002 n.s. & .025 & \\
\hline Personnel $\rightarrow$ Formal protection & $.24 * *$ & 2.339 & \\
\hline Age $\rightarrow$ Formal protection & -.014 n.s. & .298 & \\
\hline Turnover $\rightarrow$ Informal protection & $-.057 \mathrm{n} . \mathrm{s}$. & .965 & \\
\hline Personnel $\rightarrow$ Informal protection & .042 n.s. & .675 & \\
\hline Age $\rightarrow$ Informal protection & .021 n.s. & .344 & \\
\hline \multicolumn{4}{|l|}{ Dependent variables } \\
\hline $\begin{array}{l}\text { Availability of protection } \rightarrow \text { Formal } \\
\text { protection }\end{array}$ & $0.351 * * *$ & 5.361 & .41 \\
\hline $\begin{array}{l}\text { Safety/Manageability of } \\
\text { collaboration } \rightarrow \text { Formal protection }\end{array}$ & $.300 * * *$ & 4.932 & .41 \\
\hline $\begin{array}{l}\text { Availability of protection } \rightarrow \text { Informal } \\
\text { protection }\end{array}$ & $.326 * * *$ & 5.103 & .24 \\
\hline $\begin{array}{l}\text { Inconvenience of protection } \rightarrow \text { Informal } \\
\text { protection }\end{array}$ & $.127 *$ & 1.725 & .24 \\
\hline $\begin{array}{l}\text { Preservation of the prerequisites of } \\
\text { innovation } \rightarrow \text { Informal protection }\end{array}$ & $.243 * * *$ & 3.819 & .24 \\
\hline
\end{tabular}

Notes: *** Significance $<0.005$; $* *$ Significance $<0.01$; * Significance $<0.05$; ${ }^{\text {S Significance }<0} .10$ 
Table 6 Results of testing for the formal mechanisms model

\begin{tabular}{|c|c|c|c|}
\hline Path & Path coefficient & t-value & $\mathrm{R}^{2}$ \\
\hline \multicolumn{4}{|l|}{ Control variables } \\
\hline Turnover $\rightarrow$ IPR & .016 n.s. & .154 & \\
\hline Personnel $\rightarrow$ IPR & $.243^{* * *}$ & 2.15 & \\
\hline Age $\rightarrow$ IPR & .014 n.s. & .294 & \\
\hline Turnover $\rightarrow$ Contracts & -.041 n.s. & .539 & \\
\hline Personnel $\rightarrow$ Contracts & $.12^{\mathrm{a}}$ & 1.597 & \\
\hline Age $\rightarrow$ Contracts & -.066 n.s. & 1.169 & \\
\hline \multicolumn{4}{|l|}{ Dependent variables } \\
\hline Availability of protection $\rightarrow$ IPR & $0.375 * * *$ & 6.059 & .41 \\
\hline $\begin{array}{l}\text { Safety/Manageability of } \\
\text { collaboration } \rightarrow \text { IPR }\end{array}$ & $.259 * * *$ & 4.249 & .41 \\
\hline Availability of protection $\rightarrow$ Contracts & $.138^{\mathrm{a}}$ & 1.571 & .14 \\
\hline $\begin{array}{l}\text { Safety/Manageability of collaboration } \\
\rightarrow \text { Contracts }\end{array}$ & $.251 * * *$ & 2.895 & .14 \\
\hline
\end{tabular}


Table 7 Results of testing for the informal mechanisms model

\begin{tabular}{|c|c|c|c|}
\hline Path & Path coefficient & t-value & $\mathrm{R}^{2}$ \\
\hline \multicolumn{4}{|l|}{ Control variables } \\
\hline Turnover $\rightarrow$ HRM & -.029 n.s. & .32 & \\
\hline Personnel $\rightarrow$ HRM & $.135^{\mathrm{a}}$ & 1.582 & \\
\hline Age $\rightarrow$ HRM & -.032 n.s. & .455 & \\
\hline Turnover $\rightarrow$ Tacitness & -.067 n.s. & .956 & \\
\hline Personnel $\rightarrow$ Tacitness & -.009 n.s. & .124 & \\
\hline Age $\rightarrow$ Tacitness & $.079^{a}$ & 1.309 & \\
\hline Turnover $\rightarrow$ Secrecy & -.011 n.s. & .09 & \\
\hline Personnel $\rightarrow$ Secrecy & .024 n.s. & .15 & \\
\hline Age $\rightarrow$ Secrecy & -.071 n.s. & 1.199 & \\
\hline \multicolumn{4}{|l|}{ Dependent variables } \\
\hline Availability of protection $\rightarrow \mathrm{HRM}$ & $.272 * * *$ & 3.927 & .20 \\
\hline Availability of protection $\rightarrow$ Tacitness & $.225 * * *$ & 2.945 & .14 \\
\hline Availability of protection $\rightarrow$ Secrecy & $.306^{* * *}$ & 4.244 & .18 \\
\hline Inconvenience of protection $\rightarrow \mathrm{HRM}$ & .042 n.s. & .568 & .20 \\
\hline Inconvenience of protection $\rightarrow$ Tacitness & $.146^{*}$ & 1.933 & .14 \\
\hline Inconvenience of protection $\rightarrow$ Secrecy & .058 n.s. & .784 & .18 \\
\hline $\begin{array}{l}\text { Preservation of the prerequisites of } \\
\text { innovation } \rightarrow \text { HRM }\end{array}$ & $.245^{* * *}$ & 3.065 & .20 \\
\hline $\begin{array}{l}\text { Preservation of the prerequisites of } \\
\text { innovation } \rightarrow \text { Tacitness }\end{array}$ & $.163 *$ & 2.307 & .14 \\
\hline $\begin{array}{l}\text { Preservation of the prerequisites of } \\
\text { innovation } \rightarrow \text { Secrecy }\end{array}$ & $.192 * * *$ & 2.744 & .18 \\
\hline
\end{tabular}

Notes: $* * *$ Significance $<0.005 ; * *$ Significance $<0.01$; * Significance $<0.05$; a Significance $<0.10$ 
Table 8 Summary of findings

\begin{tabular}{|c|c|}
\hline \multicolumn{2}{|l|}{ Hypotheses } \\
\hline $\begin{array}{l}\text { Hypothesis 1: There is a positive relationship between availability of } \\
\text { formal mechanisms and the use of formal protection. }\end{array}$ & Supported \\
\hline $\begin{array}{l}\text { Hypothesis 2: There is a positive relationship between making } \\
\text { collaboration more manageable and safer, and the use of the formal } \\
\text { protection. }\end{array}$ & Supported \\
\hline $\begin{array}{l}\text { Hypothesis 3: There is a positive relationship between availability of } \\
\text { formal mechanisms and the use of informal protection. }\end{array}$ & Supported \\
\hline $\begin{array}{l}\text { Hypothesis 4: There is a positive relationship between inconvenience of } \\
\text { formal mechanisms and the use of informal protection. }\end{array}$ & Supported \\
\hline $\begin{array}{l}\text { Hypothesis 5: There is a positive relationship between preservation of } \\
\text { the prerequisites of innovation and the use of informal protection. }\end{array}$ & Supported \\
\hline
\end{tabular}

